\title{
Anatomical Pathophysiological and Pathogenesis of UTI
}

\section{Edwin Dias}

Professor and HOD, Department of Pediatrics, Srinivas Institute of Medical Science and Research Center, Mangalore, India

E-mail: dredwindias@gmail.com

Type of the Paper: Medical Case Study.

Type of Review: Peer Reviewed.

Indexed In: OpenAIRE.

DOI: http://dx.doi.org/10.5281/zenodo.1242619.

Google Scholar Citation: IJHSP

\section{How to Cite this Paper:}

Dias, Edwin. (2018). Anatomical Pathophysiological and Pathogenesis of UTI. International Journal of Health Sciences and Pharmacy (IJHSP), 2(1), 18-28.

DOI: http://dx.doi.org/10.5281/zenodo.1242619.

International Journal of Health Sciences and Pharmacy (IJHSP)

A Refereed International Journal of Srinivas University, India.

(C) With Authors.

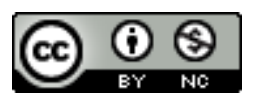

This work is licensed under a Creative Commons Attribution-Non Commercial 4.0 International License subject to proper citation to the publication source of the work.

Disclaimer: The scholarly papers as reviewed and published by the Srinivas Publications (S.P.), India are the views and opinions of their respective authors and are not the views or opinions of the SP. The SP disclaims of any harm or loss caused due to the published content to any party. 


\title{
Anatomical Pathophysiological and Pathogenesis of UTI
}

\author{
Edwin Dias \\ Professor and HOD, Department of Pediatrics, Srinivas Institute of Medical Science and \\ Research Center, Mangalore, India \\ E-mail: dredwindias@gmail.com
}

\begin{abstract}
UTI is initiated and caused by a number of factors, an understanding of the causation helps to Diagnose and treat it adequately. Organisms and host factors responsible for the occurrence and pathogenesis, are crucial in the diagnosis and treatment to prevent serious sequelae. Ecoli is a main organism causing UTI.
\end{abstract}

Keywords: UTI, Ecoli Treatment.

\section{INTRODUCTION :}

Urinary tract infection (UTI) is the most common disease in infants and the second most common infectious disease in toddlers.In children, UTI frequency, clinical symptoms and the causative pathogens vary according to sex and age. Moreover because of a wide variety of non-specific and systemic symptoms, it is difficult to perform tests for early diagnosis and the resultant inaccurate diagnosis may lead to antibiotic abuse. Thus in many cases, a severe renal injury occurs even before the UTI is diagnosed. For this reason, an early and accurate diagnosis through careful examination and tests can help in preventing severe renal injuries through adequate treatment and careful follow-up. UTI recurs easily if it is accompanied with anatomical anomalies of the urinary system. If it is not treated adequately or occurs recurrently, UTI may develop into chronic pyelonephritis resulting in hypertension and loss of renal function, a condition normally seen in 15-20\% of the cases of chronic renal failure [1].

\section{Pathophysiology and pathogenesis}

UTI is thought to initiate when a bacterial clone from the intestinal flora colonizes the periurethra and then ascends into the bladder. E.coli typically colonizes the gastrointestinal tract of humans already within few hours after birth. Some well-established E. coli clones can acquire specific virulence attributes with increased ability to adapt to new niches [2]. Virulence properties are frequently encoded in specific genetic elements, so called 'pathogenicity islands'. Only the most successful combination of virulence factors has persisted to form a specific type uropathogenicE.coli. The subset of E.coli that causes uncomplicated cystitis and acute pyelonephritis is distinct from the commensal E.coli strains. These phenotypic characteristics include specific adhesins, toxins, siderophores, proteases and the capsule as well as hydrophobicity and serum resistance [3-4]. UropathogenicE.coli uses a multi-step scheme of pathogenesis which consists of adhesion and colonization, invasion, survival, multiplication and host damage. Accordingly, bacterial virulence factors could be divided into adhesion/colonization factors, survival/immune escape factors and toxins [5]. Virulence factors associated with E.Coli urinary tract infection isolates [5]:-

1) Expression of certain O: K: H Serotypes

2) K polysaccharide capsule

3) Adherence to uroepithelial cells

4) Resistance to serum bactericidal activity

5) Hemolysin production.

6) Aerobactin production

7) Possible factors include:

a) Bacterial generation time in urine

b) Bacterial ureteroplegic factor

c) Colicin V production

d) Salicin fermentation.

Adherence of bacteria to Uroepithelial cells is a prerequisite for colonization, persistence and infection. In a system of continuous urinary flow including the powerful effect of micturition, pathogens must bind to epithelial surface to cause disease [6]. According to 
Zafriri D, Gron Y et al (1987) adherent bacteria not only persist within the urinary tract but may have growth advantages and enhanced toxicity as a result of proximity to products restricted in their diffusion that are secreted by eukaryotic cells. This could result in more effective delivery of toxins to the cells [7]. Varian S. et al (1980) observed relationship between in vitro adherence of E.Coli and severity of urinary tract infection in vivo [7]. Bacteria with $\mathrm{P}$ fimbriae are more likely to cause pyelonephritis. Between 76 and $94 \%$ of pyelonephritogenic strains of Escherichia coli have P. fimbriae, compared with $19-23 \%$ of Cystitis strains [8].

According to Thulesius O. et al (1987) lipopolysaccharide also acts to reduce ureteric peristalsis, hence facilitating ascent of Escherichia coli via the relatively dilated hypotonic ureters to the kidneys [8].Leying et al (1990) reported that capsular K1 expression is a prerequisite for serum resistance and loss of ability to synthesize K1 leads to loss of serum resistance [9].According to Hughes C. et al (1983) hemolysins are thought to contribute to spread of Escherichia coli within renal parenchyma [10].Stuart SJ et al (1980) identified two mechanisms of iron uptake in Escherichia coli, the hydroxymate type of siderophore, aerobactin and the catechol type of siderophore, enterochelin [11].

\section{ADHESION AND COLONIZATION :}

Pathogenic E. coli possess specific adherence factors that allow them to colonize different sites that E.coli do not normally inhabit. Adhesion to the cells could be a function of physiochemical surface properties of the bacterium as determined by a specific composition of lipopolysaccharides (LPS) and the capsule and often described as hydrophobicity $[12,13]$. The saccharide part of LPS is usually referred to as Oantigen. Interestingly, only a small number of $\mathrm{O}$ serogroups has phenotypes that are epidemiologically associated with urinary tract infection $[14,15]$.

In addition to LPS and the capsule, pathogenic E. coli express a number of distinct adhesins. Adhesins usually form definite morphological structures called fimbriae (also called pili) or fibrille. Fimbriae are rod-like structures of 5$10 \mathrm{~nm}$ in diameter. Fibrille on the other hand, are only 2-4 $\mathrm{nm}$ in diameter and are either long and wiry or curly and flexible .Uropathogenic E. coli are characterized by type 1 fimbriae, $P$. fimbriae, S. fimbriae, F1C fimbriae and adhesins [16,17]. In early stages of urinary tract infection, type 1 fimbriae seem to be important. Type 1 fimbriated E. coli attach to mannose moieties of the uroplakin receptors that coat transitional uroepithelial cells [18, 20]. In strains that cause cystitis, type 1 fimbriae are continually expressed and the infection is confined to the bladder [21]. In pyelonephritic strains, on the other hand, the type 1 fimbriae expression turns 'off' [22]. This may allow the organism to ascend through ureters to the kidneys, where the bacterium can attach by $\mathrm{P}$ fimbriae to digalactoside receptors that are expressed on the kidney epithelium [23, 25]. S. fimbriae and F1C fimbriae have also been shown to bind to epithelial and endothelial cells from the kidney and lower urinary tract $[26,27]$. Dr fimbriae on the other hand, bind to type IV collagen and decay-accelerating factor and enable E.coli to persist longer in the renal interstitium [28]. Thin aggregative fimbriae also called curli, are expressed on about $50 \%$ of urinary E. coli isolates. They have been suggested to promote the colonization of the perineal area and to initiate subsequent UTI. Some uropathogenic E. coli strains have been shown to also express flagella. Flagella are up to $15 \mu \mathrm{m}$ long complex organelles, which contribute to bacterial mobility. In contrast to enterotoxigenic E. coli, the role of flagella in the colonization of urinary tract seems to be of a subordinate importance [29].

\section{SURVIVAL AND IMMUNE ESCAPE :}

Pathogenic E.coli has developed several strategies to survive in an environment, which is sometimes not very favourable and poor of nutrients. Similarly bacteria have learned to protect themselves from attacks of the immune system and exogenous antibiotics. Amongst these protective factors, siderophores, capsule and biofilm appear to be the most important. Aerobactin, an example of a siderophore, enhances iron uptake and thus promotes the survival and growth of bacteria within the urinary tract [30]. Recent findings indicate that bacteria in their natural environment grow in a rather complicated multicellular state, 
biofilm[31].Curli fimbriae and cellulose are the major extracellular components of biofilm produced by the family Enterobacteriacae [32].Biofilm is a structurally complex and dynamic system that helps bacteria to survive in different environments and to be protected from both the immune system and the antibiotic treatment $[33,34]$. In addition to the biofilm formation, E. coli are able to produce a polysaccharide capsule, which substantially increases bacterial survival within the urinary tract and increases resistance to serum and to phagocytosis [35,36].

\section{TOXINS :}

E. coli produce a number of toxins, which are either associated with the membrane or secreted. Toxins participate in the pathogenesis of UTI by different mechanisms. LPS, bacterial endotoxin, a principal component of the bacterial cell membrane is recognized by the immune system and initiates local and systemic response. Its toxicity relates to the side effects of triggered immune reaction [37]. Secreted hemolysin can induce distinct oscillations of calcium concentration in renal epithelial cells or even cell necrosis [38].

The mechanisms of action of cytotoxic necrotizing factor-1 (CNF-1) involve the Rhodependent rearrangement of the cytoskeleton in eukaryotic cells with a complex of consequences. CNF-1 can either hinder cells from apoptosis or even induce apoptosis depending on the cell type and the dose [39, 40]. Moreover, by influencing the phagocytosis and adherence of polymorphonuclear leukocytes, CNF-1 could facilitate the growth of bacteria in the urinary tract [41]. In addition, CNF-1 can enhance the secretion of proinflammatory cytokines in human uroepithelial cells [42]. Despite many in vitro effects, there have been conflicting results about the role of CNF-1 in vivo. Secretion of another toxin, Sat, damages glomeruli and causes vacuolization in the surrounding epithelium. Also Pic and Tsh proteases have been shown to be associated with uropathogenic and not fecal E. coli strains [43-45].

\section{VIRULENCE FACTORS IN NON ESCHERICHIA COLI UROPATHOGENS}

pathogen outside the urinary tract, is an important uropathogen in young adult women that predominantly causes cystitis. According to Hovelius B, Mardh PA et al (1984) Staphlococcussaprophyticus may have a predilection for causing urinary tract infection by virtue of its avid adherence to uroepthielial cells [46].

Other Enterobacteriaceae, including Klebsiella species and Proteus species as well as Providenciastuartii have been shown to express fimbriae that are important in both uroepithelial adherence and attachment to urinary catheters. Staphylococcus epidermidis uncommonly causes infection in non catheterized patients and is a frequent cause of lower urinary tract infection in catheterized patients by virtue of its capacity to attach to and form a biofilm on foreign bodies, including catheters [47].

\section{(1) ROUTES OF INFECTION}

Microorganisms can reach the urinary tract by way of the ascending, hematogenous, or lymphatic routes.

\section{(2) ASCENDING ROUTE OF INFECTION}

Ascent of microorganisms within the urethra from external sources represents the most common pathway for urinary tract infection, especially for organisms of enteric origin, i.e. Escherichia coli and other Enterobacteriaceae. In females, the urethra is shorter and is more liable to contamination with colonic flora that resides on the perineal skin. In males, the greater length of urethra and the antibacterial properties of prostatic secretions are effective barriers to invasion by this route [48].

A single insertion of a catheter into the urinary bladder in ambulatory patients results in urinary infection $1 \%$ to $2 \%$ of the time according to Hinman F. Jr (1966). Indwelling catheters with open drainage systems result in urinary tract infection in almost $100 \%$ of cases within 3 to 4 days. Use of closed drainage systems, which greatly delays the onset of infection, is strong evidence for the ascending route in patients with catheters [49].

Bladder microorganisms may further ascend the ureters even against the downward flow of urine, especially if facilitated by vesicouretric reflux to reach the renal pelvis, where they may penetrate the kidney via backflow into the renal collecting system or via lymphatics [50].

Staphylococcus sarprophyticus, an uncommon 


\section{(3) HAEMATOGENOUS ROUTE OF INFECTION}

Haematogenous infection of the urinary tract is restricted to a few relatively uncommon uropathogens such as Staphylococcus aureus, Candida species, Salmonella and Mycobacterium tuberculosis, which cause primary infection elsewhere in the body [50].

\section{(4) LYMPHATIC ROUTE OF} INFECTION

Spread of infection to the primary tract via lymphatics remains speculative [50].

\section{(5) HOST FACTORS}

The urinary tract is one of the exclusive areas of the body which normally resists microbes' growth despite its close proximity to the outside environment and frequent bacterial entry. Various factors are involved in bacterial clearance, both constitutive and those inducible by the presence of a pathogen.Following spread of microorganisms to the urinary tract, the outcome depends on bacterial virulence factors and on host defences in the urine, bladder, ureters and kidneys [51].

\section{(6) URINE}

The urine may be inhibitory or even bactericidal against small inocula of uropathogens. The most important inhibitory factors in urine are high osmolality, urea concentration, organic acid concentration, low PH. Oligosaccharide and Uromucoid (Tamm Horsfall protein) are found in normal urine which may competitively inhibit attachment of E.Coli to the mucosal surface of the urinary tract by aggregating bacteria in the urine. Finally antibody known to be released into urine in patients with renal disease has been shown to inhibit adherence to uroepithelial cells in vitro. Modification of the chemical composition of the urine in certain clinical conditions or with medication can alter ability of urine to support growth of microorganisms. For example, glucose in diabetic urine enhances the growth of uropathogens, such as Escherichia coli and Candida albicans. When the $\mathrm{pH}$ of the urine is about 5 , the urine is inhibitory as a result of conversion of naturally occurring weak organic acids to the unionized form that has antibacterial activity [52].

Changes in the environment in the urine may have an opposite effect on host defences in other areas of the urinary tract. For example acidification stimulates renal production of ammonia which inactivates the fourth component of complement, an essential factor for phagocytosis in renal tissues. Thus acidification which may enhance urinary defences simultaneously diminishes renal defences. Water diuresis enhances urinary defences by a number of mechanisms. Water diuresis increases medullary blood flow, which enhances delivery of phagocytic cells and antibacterial substances to the renal tissues. It abolishes the normally high medullary osmolality which interferes with the action of complement and the migration of phagocytes into the renal parenchyma. Water diuresis bolsters bladder defences by increasing bladder emptying. Nevertheless, the delicate balance between host defences in various portions of the urinary tract and microbial multiplication can be altered by water diuresis in favour of renal infection by enhancing vesicoureteric reflux or by diluting the antibacterial substances in the urine [52].

The Tamm-Horsfall protein has been shown to block the adherence of type 1 piliatedE.coli to uroplakin receptors [53]. SecretoryIgA and low molecular weight sugars can block the adherence of uro-pathogens [54-56]. Lactoferrin inhibits the growth of bacteria by decreasing the accessibility of iron and the antimicrobial peptides cathelicidin and defensin directly kill bacteria by destroying their membrane [57-59].

\section{(7) VAGINAL INTROITUS}

The vaginal mucosa is normally colonized by lactobacillus, despite close proximity and probable frequent contamination with large number of enteric organisms. However, women at risk of urinary tract infection have been noted to have enteric organisms colonizing the mucosal surfaces of the vaginal introitus. This has been attributed to increased receptivity of vaginal and uroepithelial cells for attachment of E.Coli in these patients. The increased receptivity is perhaps controlled by genetic factors, as reflected by prevalence of certain HLA types or blood group substances among those with urinary tract infection. Blood group substances that appear on the surfaces of uroepithelial cells may either function as receptors for attachment of bacterial surface structures or block attachment to less prominent receptors [60]. 


\section{(8) BLADDER}

Mechanical removal of bladder microorganisms by dilution with fresh urine, followed by complete emptying of the bladder removes the bulk of contaminated urine. But micturition leaves behind a film of contaminated urine on the surface of the bladder mucosa that is sufficient to maintain colonization. However, the effectiveness of antibacterial properties of bladder mucosa in clearing surface contamination is established. Surface mucin coating of the bladder mucosa plays a role in preventing bacterial attachment and subsequent colonization. However, using mathematical simulation and in vivo models suggested that emptying of the bladder is only one of the defence mechanisms and additional antibacterial factors are essential [61-63]. The mucosa of the urinary bladder has been shown to possess bacteriostatic properties in vitro [64].

\section{(9) URETER}

Ureteral peristalsis facilities flow of urine from the kidney to the bladder. Diminished ureteral peristalsis contributes to the increased susceptibility to UTI during pregnancy. The efficacy of bladder emptying is maintained by competent vesicoureteral valve action which prevents contaminated bladder urine from going up the ureters during voiding and allows only fresh urine to flow into the bladder when voiding is complete. Althougheven under normal conditions, microorganisms can ascend against the flow of urine [65].

Vesicoureteral reflux is gross passage of bladder urine up the ureters on voiding. Reflux impairs the efficiency of bladder emptying by producing residual ureteral urine. Reflux occurs in children as a congenital developmental anomaly. In children if reflux is severe, it may exert sufficient hydrostatic pressure on the renal pelvis to impair renal growth even in the presence of sterile urine. In the presence of infected urine, reflux can rapidly destroy the kidney. As with reflux, extrarenal obstruction, due to stones, extrinsic compression of the ureters, congenital urinary tract anatomic anomalies or tumours can exert destructive hydrostatic pressure on the kidney and prevent efficient emptying of the urinary outflow tract. Although obstruction itself does not increase contamination of urine with uropathogens from external sources, the presence of obstruction increases the risk of renal infection.Studies have identified a heat sensitive calcium ionophore by some uropathogens that inhibits ureteral peristalsis $[65,66]$.

\section{(10) KIDNEY}

The Renal cortex is much more resistant to infection than the medulla, for both gramnegative bacilli and gram positive cocci that reach the kidney by either the haematogenous or ascending routes. High concentration of ammonia, high osmolality, the relative anoxic state and relatively low blood flow in the renal medulla impede humoral and cellular defences [67].

\section{IMMUNE RESPONSE :}

The immune response appears to have limited role in both renal and bladder infection. Both systemic and local antibody production occur in renal infection, with type - specific antibody detectable in the urine even before antibody can be detected in the serum. Urinary antibody may function by decreasing adherence of bacteria to uroepithelial cells [68].

ANTI - ADHERENCE HOST DEFENSE MECHANISMS [69,70]

The anti-adherence mechanisms in the urinary tract may be specific or non-specific, interfering with colonization of all organisms.

1. The normal bacterial flora of the vaginal introitus, periurethral region, and urethra may cause stearic hindrance and make receptors less available.

2. The Uromucoid or urinary slime (Tamm Horsfall protein) rich in mannose residues avidly bind E.Coli and may prevent attachment to uroepithelial cells.

3. ImmunoglobulinsIgG, IgA, and SIgA in the urine of patients with pyelonephritis have inhibited adherence of the responsible strain of E.Coli to the uroepithelial cells.

4. The transitional cells of bladder mucosa are coated by a thin layer of mucopolysaccharide which interferes with adhesion of microorganisms.

5. Normal urine contains numerous oligosaccharides including manno oligosaccharides that inhibit type 1 fimbriae attachment.

6. Finally the mechanical effect of flushing during bladder emptying is essential in preventing adherence [69, 70]. 
The presence of bacterium induces a robust immune response already after a brief short contact with uroepithelial cells. Bladder superficial epithelial cells express Toll-like receptor-4 (TLR-4) on their membranes which together with its co-receptors CD-14 and MD2 recognize lipopolysaccharide from bacteria and activate innate immune response [71,72]. However, there are conflicting results regarding the expression of CD-14 on uroepithelial cells. Several studies showed the presence of CD-14 by protein and mRNA expression [73-75]. Other groups, in contrast, did not detect CD-14 on uroepithelial cells suggesting that the response of uroepithelial cells to LPS requires the presence of type 1 or P-fimbrie [76, 77].The latter mechanism could explain the strong immune response to virulent strains expressing fimbriae which is absent in the presence of non-virulent strains causing asymptomatic bacteriuria [78-79]. Alternatively urinary soluble CD-14 was proposed to co-mediate LPS-signalling, although it remains unclear if its urinary levels in health are high enough for such an effect [80].

During pyelonephritis, renal tubular epithelial cells are the main cells to react to the presence of bacteria [81]. However, the mechanism of sensing bacteria has also here been a matter of debate and conflicting results. Renal tubular cells neither expressedCD14 nor TLR-4 nor were hypo responsive to LPS stimulation. Others, in contrast were able to detect TLR-4 on renal tubular epithelial cells. Epithelial cells within the urinary tract appear to be not just a mechanical barrier but also an active part of the innate immune system sensing bacteria and triggering the cascade of immune response to them [82].

After contact with bacteria, epithelial cells react by different ways. First, bladder epithelium exfoliates superficial facet cells, which could clear the bacteria from the bladder. Epithelial cells may contribute to the defence by the production of substances toxic to bacteria, like cathelicidin and nitric oxideor by engagement of other cells by simultaneous production of chemokines and proinflammatory cytokines. Chemokines attract professional immune system cells and cytokines activate them. Out of a number of chemokines and proinflammatory cytokines, interleukin 8 (IL-8) seems to be of crucial importance because of its chemo attraction of neutrophils. Cytokine mediated up regulation of adhesion molecules and cytokine receptors facilitates the process of transmigration. Amongst them, CXCR1 receptor on renal epithelial cells has been shown to be of importance for transepithelial migration of granulocytes and bacterial clearance during urinary tract infection. Neutrophils kill bacteria by different mechanisms, either phagocytosis or the release of the toxic content of their granules. The influx of neutrophils is followed by an influx of other professional immune cells namely monocytes, macrophages and lymphocytes, which are predominantly important in later stages of infection [83].

\section{CONCLUSION :}

A host of factors predispose to UTI in children as described above, an understanding of the microbiological and the variety of non-specific and systemic symptoms, it is difficult to perform tests for early diagnosis and the resultant inaccurate diagnosis may lead to antibiotic abuse. Thus in many cases, a severe renal injury occurs even before the UTI is diagnosed. For this reason, an early and accurate diagnosis through careful examination and tests can help in preventing severe renal injuries through adequate treatment and careful follow-up. UTI recurs easily if it is accompanied with anatomical anomalies of the urinary system. If it is not treated adequately or occurs recurrently, UTI may develop into chronic pyelonephritis resulting in hypertension and loss of renal function, a condition normally seen in 15-20\% of the cases of chronic renal failure [84].

\section{REFERENCES :}

[1] Yoon JE, Kim WK, Lee JS, Shin KS, Ha TS. Antibiotic susceptibility and imaging findings of the causative microorganisms responsible for acute urinary tract infection in children: a five-year single center study. Korean J Pediatr 2011; 54(2): 79-85.

[2] Kaper JB, Nataro JP, Mobley HL. Pathogenic Escherichia coli. Nat Rev Microbiol 2004; 2: 123-40.

[3] Manges AR, Johnson JR, Foxman B, O'Bryan TT, Fullerton KE, Riley LW. Wide 
spread distribution of UTI caused by a multidrug-resistant Escherichia coli clonal group. N Engl J Med 2001; 345: 1007-13.

[4] Ohman L, Normann B, Stendahl O. Physicochemical surface properties of Escherichia coli strains isolated from different types of UTI. Infect Immun 1981; 32: 951-5.

[5] Tullus K, Jacobson SH, Katouli M, Brauner A. Relative importance of eight virulence characteristics of pyelonephritogenic Escherichia coli strains assessed by multivariate statistical analysis. J Urol 1991; 146: 1153-5.

[6] Fowler JE, Stamey TA. Studies of introital colonization in women with recurrent urinary infections. The role of bacterial adherence. J Urol 1997; 117: 472.

[7] Varian SA, Cooke EM. Adhesive properties of Escherichia coli from urinarytract infections. J Med Microbiol 1980; 13: 111.

[8] Thulesius 0, Araj G. The effect of Uropathogenic bacteria on ureteral motility.Urol Res 1987; 15: 273.

[9] Leying H, Suerbaum S, Kroll HP, Stahl D, Opferkuch W. The capsular polysaccharide a major determinant of serum resistance in K-l positive blood culture isolates of Escherichia coli. Infects Immun 1990; 58: 222.

[10] Huges C, Hacker J, Roberts A, Goebel W. Hemolysin production as virulence marker in symptomatic and asymptomatic UTI caused by Escherichia coli. Infects Immun 1983; 39: 546.

[11] Stuart SJ, Greenwood KT, Luke RKJ.Hydroxamate-mediated transport of iron controlled by Col. V plasmids. J Bacteriol 1980; 243: 35.

[12] Ohman L, Normann B, Stendahl O. Physicochemical surface properties of Escherichiacolis trains isolated from different types of UTI. Infect Immun 1981; 32:951-5.

[13] TullusK, Jacobson S H, KatouliM, BraunerA. Relative importance of eight virulence characteristics of pyelonephritogenic Escherichiacolis trains assessed by multivariatestatisticalanalysis. JUrol 1991; 146:1153-5.

[14] Orskov I, Orskov F, Birch-Andersen A,
Kanamori M, SvanborgEden CO. K, H and fimbrial antigens in Escherichia coli serotypes associated with pyelonephritis and cystitis. Scand J Infect DisSuppl 1982; 33: 18-25.

[15] Johnson JR, Orskov I, Orskov F. O, K, and $\mathrm{H}$ antigens predict virulence factors, carboxyl esterase B pattern, antimicrobial resistance, and host compromise among Escherichia coli strains causing urosepsis. J Infect Dis 1994; 169: 119-26.

[16] Guyer DM, Gunther NWT, Mobley HL. Secreted proteins and other features specific to Uropathogenic Escherichia coli. J Infect Dis 2001; 183(1): S32-5.

[17] Mulvey MA. Adhesion and entry of Uropathogenic Escherichia coli. Cell Microbiol 2002; 4: 257-71.

[18] Gunther NWT, Lockatell V, Johnson DE, Mobley HL. In vivo dynamics of type 1 fimbriae regulation in Uropathogenic Escherichia coli during experimental urinary tract infection. Infect Immun 2001; 69: 283846.

[19] Bahrani-Mougeot FK, Buckles EL, Lockatell CV. Type 1 fimbriae and extracellular polysaccharides are preeminent Uropathogenic Escherichia coli virulence determinants in the murine urinary tract. MolMicrobiol 2002; 45: 1079-93.

[20] Connell I, Agace W, Klemm P, Schembri M, Marild S, Svanborg C. Type 1 fimbriae expression enhances Escherichia coli virulence for the urinary tract. Proc NatlAcadSci U S A 1996; 93: 9827-32.

[21] Svanborg-Eden C, Svennerholm AM. Secretory immunoglobulin A and $\mathrm{G}$ antibodies prevent adhesion of Escherichia coli to human urinary tract epithelial cells. Infect Immun 1978; 22: 790-7.

[22]HedlundM, FrendeusB, WachtlerC, HangL, FischerH, SvanborgC. Type1fimbriaedeliveranLPS-andTLR4dependentactivationsignaltoCD14negativecells.MolMicrobiol2001; 39:542-52.

[23] Dodson KW, Pinkner JS, Rose T, Magnusson G, Hultgren SJ, Waksman G. Structural basis of the interaction of the pyelonephritic E. coli adhesion to its human kidney receptor. Cell 2001; 105: 733-43. 
[24] Marre R, Kreft B, Hacker J. Genetically engineered $\mathrm{S}$ and $\mathrm{F} 1 \mathrm{C}$ fimbriae differ in their contribution to adherence of Escherichia coli to cultured renal tubular cells. Infect Immun 1990; 58: 3434-7.

[25] Emody L, Kerenyi M, Nagy G. Virulence factors of Uropathogenic Escherichia coli. Int J Antimicrob Agents 2003; 22 (2): 29-33.

[26] Selvarangan R, Goluszko P, Singhal J. Interaction of Dradhesin with collagen type IV is a critical step in Escherichia coli renal persistence. Infect Immun 2004; 72: 4827-35.

[27] Patri E, Szabo E, Pal T, Emody L. Thin aggregative fimbriae on urinary Escherichia coli isolates. AdvExp Med Biol 2000; 485: 219-24.

[28] Ramos HC, Rumbo M, Sirard JC. Bacterial flagellins: mediators of pathogenicity and host immune responses in mucosa. Trends Microbiol 2004; 12: 509-17.

[29] Yamamoto T, Fujita K, Yokota T. Adherence characteristics to human small intestinal mucosa of Escherichia coli isolated from patients with diarrhoea or UTI. J Infect Dis 1990; 162: 896-908.

[30] Jacobson SH, Tullus K, Wretlind B, Brauner A. Aerobactin mediated uptake of iron by strains of Escherichia coli causing acute pyelonephritis and bacteraemia. J Infect 1988; 16: 147-52.

[31] Hall-Stoodley L, Costerton JW, Stoodley P. Bacterial bio films: from the natural environment to infectious diseases. Nat Rev Microbiol 2004; 2: 95-108.

[32] Zogaj X, Bokranz W, Nimtz M, Romling U. Production of cellulose and curly fimbriae by members of the family Enterobacteriaceae isolated from the human gastrointestinal tract. Infect Immun 2003; 71: 4151-8.

[33] Suthereland IW, Hughes KA, Skillman LC, Tait K. The interaction of phage and bio films. FEMS MicrobiolLett 2004; 232: 1-6.

[34] Trautner BW, Darouiche RO. Role of bio film in catheter-associated urinary tract infection. Am J Infect Control 2004; 32: 17783.

[35] Mellata M, Dho-Moulin M, Dozois CM. Role of virulence factors in resistance of avian pathogenic Escherichia coli to serum and in pathogenicity. Infect Immun 2003; 71: 536-40.

[36] Cross AS, Gemski P, Sadoff JC, Orskov F, Orskov I, Alexander C. The importance of the K1 capsule in invasive bacterial lipopolysaccharides and innate immunity. J Endotoxin Res 2001; 7: 167-202.

[37] Uhlen P, Laestadius A, Jahnukainen T. Alpha-haemolysin of Uropathogenic E. coli induces $\mathrm{Ca} 2+$ oscillations in renal epithelial cells. Nature 2000; 405: 694-7.

[38] Fiorentini C, Matarrese P, Straface E. Rho-dependent cell spreading activated by $\mathrm{E}$. coli cytotoxic necrotizing factor 1 hinders apoptosis in epithelial cells. Cell Death Differ 1998; 5: 921-9.

[39] Mills M, Meysick KC, O'Brien AD. Cytotoxic necrotizing factor type 1 of Uropathogenic Escherichia coli kills cultured human uroepithelial cells by an apoptotic mechanism. Infect Immun 2000; 68: 5869-80.

[40] Hofman P, Le Negrate G, Mograbi B. Escherichia coli cytotoxic necrotizing factor-1 (CNF-1) increases the adherence to epithelia and the oxidative burst of human polymorphonuclear leukocytes but decreases bacteria phagocytosis. J LeukocBiol 2000; 68: 522-8.

[41] Falzano L, Quaranta MG, Travaglione S. Cytotoxic necrotizing factor 1 enhances reactive oxygen species-dependent transcription and secretion of proinflammatory cytokines in human uroepithelial cells. Infect Immun 2003; 71: 4178-81.

[42] Johnson DE, Drachenberg C, Lockatell CV, Island MD, Warren JW, Donnenberg MS. The role of cytotoxic necrotizing factor-1 in colonization and tissue injury in a murine model of urinary tract infection. FEMS Immunol Med Microbiol 2000; 28: 37-41.

[43] Rippere-Lampe KE, O'Brien AD, Conran $\mathrm{R}$, Lockman HA. Mutation of the gene encoding cytotoxic necrotizing factor type 1 attenuates the virulence of Uropathogenic Escherichia coli. Infect Immun 2001; 69: 3954-64.

[44] Guyer DM, Henderson IR, Nataro JP, Mobley HL. Identification of sat, an auto transporter toxin produced by Uropathogenic 
Escherichia coli. MolMicrobiol 2000; 38: 5366.

[45] Heimer SR, Rasko DA, Lockatell CV, Johnson DE, Mobley HL. Auto transporter genes pic and tsh are associated with Escherichia coli strains that cause acute pyelonephritis and are expressed during urinary tract infection. Infect Immun 2004; 72: 593-7.

[46] Hovelius B, Mardh PA. Staphylococcus saprophyticus as a common cause of urinary tract infection. Rev infectDis 1984; 6: 328.

[46] Mobley HLT, Chippendale GR, Tenney JH, Hull RA, Warren JW. Expression type 1 fimbriae may be required for persistence of Escherichia coli in the catheterized urinary tract. J clinMicrobiol 1987; 25: 2253.

[47] Pfau A, sacks T. The bacterial flora of the vaginal vestibule, urethra and vagina in premenopausal women with recurrent UTI. J Urol 1981; 12: 630.

[48] Hinman F Jr. Mecahnism for the entry of bacteria and the establishment of urinary infection in female children. J Urol 1966; 96: 546.

[49] Hooton TM, Scholes D, Stapleton AE. A prospective study of asymptomatic bacteriuria in sexually active young women. $\mathrm{N}$ Engl $\mathrm{J}$ Med 2000; 343: 992-7.

[50]PfauA,sacksT.Thebacterialfloraofthevagin alvestibule,urethraandvaginainpremenopausal womenwithrecurrentUTI.JUrol1981; 12:630.

[51]

HootonTM,ScholesD,StapletonAE.Aprospecti vestudyofasymptomaticbacteriuriainsexuallyac tiveyoungwomen.NEnglJMed2000; 343:9927.

[52] Serafini-Cessi F, Malagolini N, Cavallone D. Tamm-Horsfall glycoprotein: biology and clinical relevance. Am J Kidney Dis 2003; 42: 658-76.

[53] Bates JM, Raffi HM, Prasadan K. TammHorsfall protein knockout mice are more prone to urinary tract infection: rapid communication. Kidney Int 2004; 65: 791-7.

[54] Fliedner M, Mehls O, Rauterberg EW, Ritz E. Urinary sIgA in children with urinary tract infection. J Pediatr 1986; 109: 416-21.
[55] Bueler MR, Wiederkehr F, Vonderschmitt DJ. Electrophoretic, chromatographic and immunological studies of human urinary proteins.Electrophoresis 1995; 16: 124-34.

[56] Mulvey MA, Schilling JD, Martinez JJ, Hultgren SJ. Bad bugs and beleaguered bladders: interplay between Uropathogenic Escherichia coli and innate host defenses. Proc NatlAcadSci U S A 2000; 97: 8829-35.

[57] Abrink M, Larsson E, Gobl A, Hellman L. Expression of lactoferrin in the kidney: implications for innate immunity and iron metabolism. Kidney Int 2000; 57: 2004-10.

[58] Chromek M, Slamova Z, Bergman P. The antimicrobial peptide cathelicidin protects the urinary tract against invasive bacterial infection. Nat Med 2006; 12: 636-41.

[59] Valore EV, Park CH, Quayle AJ, Wiles KR, McCray PB, Ganz T. Human betadefensin-1: an antimicrobial peptide of urogenital tissues. J Clin Invest 1998; 101: 1633-42.

[60] Teague N, Boyarsky S. Further effects of coliform bacteria on urethral peristalsis. J Urol 1968; 99: 720.

[61] Gordon DM, Riley MA. A theoretical and experimental analysis of bacterial growth in the bladder.MolMicrobiol 1992; 6: 555-62.

[62] Cox CE, Hinman F, Jr. Experiments with induced bacteriuria, vesical emptying and bacterial growth on the mechanism of bladder defense to infection. J Urol 1961; 86: 739-48.

[63] Roberts JA. Factors predisposing to UTI in children.PediatrNephrol 1996; 10: 517-22.

[64] Norden CW, Green GM, Kass EH. Antibacterial mechanisms of the urinary bladder. J Clin Invest 1968; 47: 2689-700.

[65]

LeyingH,SuerbaumS,KrollHP,StahlD,Opferku chW.Thecapsularpolysaccharideamajordetermi nantofserumresistanceinK-l-

positivebloodcultureisolatesofEscherichiacoli.I nfectsImmun1990; 58:222.

[66]

TeagueN,BoyarskyS.Furthereffectsofcoliform bacteriaonurethralperistalsis.JUrol1968; 99:720.

[67] Kaijser B, Larsson P, Olling S, 
Schneerson R. Protection against acute ascending pyelonephritis caused by Escherichia coli in rats, using isolated capsular antigen conjugated to bovine serum albumin. Infect Immun 1983; 39: 142.

[68] Roberts JA, Hardway K, Kaack B, Fussell EN, Baskin G. Prevention of Pyelonephritis by immunization with P-fimbriae. J Urol 1984; 131: 602 .

[69]

KaijserB,LarssonP,OllingS,SchneersonR.Prote ctionagainstacuteascendingpyelonephritiscause dbyEscherichiacoliinrats, usingisolatedcapsular antigenconjugatedtobovineserumalbumin.Infec tImmun1983; 39:142.

[70]

RobertsJA,HardwayK,KaackB,FussellEN,Bas kinG.PreventionofPyelonephritisbyimmunizati onwithP-fimbriae.JUrol1984; 131:602.

[71] Valore EV, Park CH, Quayle AJ, Wiles KR, McCray PB, Ganz T. Human betadefensin-1: an antimicrobial peptide of urogenital tissues. J Clin Invest 1998; 101: 1633-42.

[72] Backhed F, Soderhall M, Ekman P, Normark S, Richter-Dahlfors A. Induction of innate immune responses by Escherichia coli and purified lipopolysaccharides correlate with organ- and cell-specific expression of Toll-like receptors within the human urinary tract. Cell Microbiol 2001; 3: 153-8.

[73] ValoreEV,ParkCH,QuayleAJ,WilesKR, McCrayPB,GanzT.Humanbeta-defensin-1: anantimicrobialpeptideofurogenitaltissues.JCli nInvest1998; 101:1633-42

[74] Samuelsson P, Hang L, Wullt B, Irjala H, Svanborg C. Toll-like receptor 4 expression and cytokine responses in the human urinary tract mucosa. Infect Immun 2004; 72: 317986.

[75] Schilling JD, Martin SM, Hunstad DA. CD14 and Toll-like receptor dependent activation of bladder epithelial cells by lipopolysaccharides and type 1 piliated Escherichia coli. Infect Immun 2003; 71: 1470-80.

[76] Chromek M, Stankowska D, Dadfar E, Kaca W, Rabbani H, Brauner A. Interleukin-8 response in cells from the human urinary tract induced by lipopolysaccharides of Proteus mirabilis O3 and O18. J Urol 2005; 173: 11-4.

[77] Hedlund M, Frendeus B, Wachtler C, Hang L, Fischer H, Svanborg C. Type 1 fimbriae deliver an LPS- and TLR4-dependent activation signal to CD14-negative cells. MolMicrobiol 2001; 39: 542-52.

[78] Frendeus B, Wachtler C, Hedlund M. Escherichia coli P fimbriae utilize the Toll-like receptor 4 pathway for cell activation. MolMicrobiol 2001; 40: 37-51.

[79] Eden CS, Hanson LA, Jodal U, Lindberg $\mathrm{U}$, Akerlund AS. Variable adherence to normal human urinary-tract epithelial cells of Escherichia coli strains associated with various forms of urinary tract infection. Lancet 1976; 1: 490-2.

[80] Bergsten G, Samuelsson M, Wullt B, Leijonhufvud I, Fischer H, Svanborg C. Pap G-dependent adherence breaks mucosal inertia and triggers the innate host response. $\mathrm{J}$ Infect Dis 2004; 189: 1734-42.

[81] Bussolati B, David S, Cambi V, Tobias PS, Camussi G. Urinary soluble CD14 mediates human proximal tubular epithelial cell injury induced by LPS. Int J Mol Med 2002; 10: 441-9.

[82] Brauner A, Soderhall M, Jacobson SH, Lundahl J, Andersson U, Andersson J. Escherichia coli-induced expression of IL-1 alpha, IL-1 beta, IL-6 and IL-8 in normal human renal tubular epithelial. J Infect Dis 2003; 173: 1638-42.

[83] BergstenG, SamuelssonM, WulltB, LeijonhufvudI, FischerH,SvanborgC.PapGdependent adherence breaks mucosalinertia and triggers the innate hostresponse .JInfectDis2004; 189:1734-42.

[84]

YoonJE,KimWK,LeeJS,ShinKS,HaTS.Antibio ticsusceptibilityandimagingfindingsofthecausat ivemicroorganismsresponsibleforacute urinarytractinfectioninchildren: afiveyearsinglecenterstudy.KoreanJPediatr2011;54( 2):79-85. 